\title{
Whole gut microbiome composition of damselfish and cardinalfish before and after reef settlement
}

\author{
Darren J. Parris $^{1}$ ， Rohan M. Brooker ${ }^{2}$ ， Michael A. Morgan ${ }^{1}$ ， Danielle L. Dixson ${ }^{2}$ ， Frank J. Stewart ${ }^{\text {Corresp. } 1}$ \\ ${ }^{1}$ School of Biology, Georgia Institute of Technology, Atlanta, Georgia, United States \\ 2 School of Marine Science and Policy, University of Delaware, Newark, Delaware, United States \\ Corresponding Author: Frank J. Stewart \\ Email address: frank.stewart@biology.gatech.edu
}

The Pomacentridae (damselfish) and Apogonidae (cardinalfish) are among the most common fish families on coral reefs and in the aquarium trade. Members of both families undergo a pelagic larvae phase prior to settlement on the reef, where adults play key roles in benthic habitat structuring and trophic interactions. Fish-associated microbial communities (microbiomes) significantly influence fish health and ecology, yet little is known of how microbiomes change with life stage. We quantified the taxonomic (16S rRNA gene) composition of whole gut microbiomes from ten species of damselfish and two species of cardinalfish from Lizard Island, Australia, focusing specifically on comparisons between pelagic larvae prior to settlement on the reef versus post-settlement juvenile and adult individuals. On average, microbiome phylogenetic diversity increased from pre- to post-settlement, and was unrelated to the microbial composition in the surrounding water column. However, this trend varied among species, suggesting stochasticity in fish microbiome assembly. Pre-settlement fish were enriched with bacteria of the Endozoicomonaceae, Shewanellaceae, and Fusobacteriaceae, whereas settled fish harbored higher abundances of Vibrionaceae and Pasteurellaceae. Several individual operational taxonomic units, including ones related to Vibrio harveyi, Shewanella sp., and uncultured Endozoicomonas bacteria, were shared between both pre and post-settlement stages and may be of central importance in the intestinal niche across development. Richness of the core microbiome shared among pre-settlement fish was comparable to that of settled individuals, suggesting that changes in diversity with adulthood are due to the acquisition or loss of host-specific microbes. These results identify a key transition in microbiome structure across host life stage, suggesting changes in the functional contribution of microbiomes over development in two ecologically dominant reef fish families. 


\author{
"Whole gut microbiome composition of damselfish and cardinalfish before and after reef \\ settlement"

\section{Contributors:} \\ Darren J. Parris ${ }^{1}$, Rohan M. Brooker ${ }^{2}$, Michael A. Morgan ${ }^{1}$, Danielle L. Dixson ${ }^{2}$, Frank J. Stewart ${ }^{{ }^{*}}$ \\ Affiliations: \\ ${ }^{1}$ School of Biology, Georgia Institute of Technology, Ford ES\&T Building, Rm 1242, \\ 311 Ferst Drive, Atlanta, GA 30332 \\ ${ }^{2}$ School of Marine Science and Policy, University of Delaware, 111 Robinson Hall, Newark, DE \\ 19716 \\ *Corresponding author. frank.stewart@biology.gatech.edu
}

\title{
ABSTRACT
}

The Pomacentridae (damselfish) and Apogonidae (cardinalfish) are among the most common fish families on coral reefs and in the aquarium trade. Members of both families undergo a pelagic larvae phase prior to settlement on the reef, where adults play key roles in benthic habitat structuring and trophic interactions. Fish-associated microbial communities (microbiomes) significantly influence fish health and ecology, yet little is known of how microbiomes change with life stage. We quantified the taxonomic (16S rRNA gene) composition of whole gut microbiomes from ten species of damselfish and two species of cardinalfish from Lizard Island, Australia, focusing specifically on comparisons between pelagic larvae prior to settlement on the reef versus post-settlement juvenile and adult individuals. On average, microbiome phylogenetic diversity increased from pre- to post-settlement, and was unrelated to the microbial composition in the surrounding water column. However, this trend varied among species, suggesting stochasticity in fish microbiome assembly. Pre-settlement fish were enriched with bacteria of the Endozoicomonaceae, Shewanellaceae, and Fusobacteriaceae, whereas settled fish harbored higher abundances of Vibrionaceae and Pasteurellaceae. Several individual operational taxonomic units, including ones related to Vibrio harveyi, Shewanella sp., and uncultured Endozoicomonas bacteria, were shared between both pre and post-settlement stages and may be of central importance in the intestinal niche across development. Richness of the core microbiome shared among pre-settlement fish was comparable to that of settled individuals, suggesting that changes in diversity with adulthood are due to the acquisition or loss of host-specific microbes. These results identify a key transition in microbiome structure across host life stage, suggesting changes in the functional contribution of microbiomes over development in two ecologically dominant reef fish families. 


\section{INTRODUCTION}

Animals harbor diverse microbial communities that influence key aspects of host health, development, and behavior. In most vertebrates, the majority of microorganisms inhabit the gastrointestinal (GI) tract at an abundance of potentially trillions of cells whose collective genome may be orders of magnitude larger than that of the host (Whitman et al. 1998; Backhed et al. 2005; Gill et al. 2006). A wealth of studies in both fish and mammalian systems now confirm the importance of a gut microbiome to host health, fitness, and development (Rawls et al. 2004, Bates et al. 2006, Chung et al. 2012; Lee \& Hase 2014), with alterations of microbiome composition affecting such properties as host immunity, susceptibility to toxins, adiposity, efficiency of nutrient acquisition, behavior and mood, and chemical signaling among conspecifics (Turnbaugh et al. 2006; Round \& Mazmanian 2009; Heijtz et al. 2011; Greenblum et al. 2012; Theis et al. 2013; Zheng et al. 2013, Wada-Katsumata et al. 2015).

Despite recognition of the important role of microbiomes in host ecology (Wong and Rawls, 2012), microbiomes remain unexplored for the vast majority of ecologically relevant taxa, including the most diverse of the vertebrate groups, the teleost fishes. Fish account for almost half of all vertebrate species on earth and span a wide spectrum of habitats, host ranges, physiologies, and ecological strategies. Studies of fish gut microbiomes have focused primarily on commercial or model species, with most targeting only a small number of host or microbial taxa (Roeselers et al. 2011; Clements et al. 2014; Llewellyn et al. 2014). These studies raise the possibility of a core set of fish gut microbes shared across diverse hosts, notably a dominance by bacteria of the Gammaproteobacteria and 
62 Firmicutes, including unique fish-associated strains of the Vibrionales and Clostridia 63 (Spanggaard et al. 2000; Al-Harbi \& Naim Uddin 2004; Martin-Antonio et al. 2007; Sullam

64

65

66

67

68

69

70

71

72

73

74

75

76

77

78

79

80

81

82

83

et al. 2012; Xing et al. 2013; Llewellyn et al. 2014). Significant variation in the fish gut microbiome has also been reported, with changes in taxonomic composition shown to affect host immunity, nutrient acquisition, and epithelial differentiation (Rawls et al. 2004; Bates et al. 2006, 2007; Cheesman \& Guillemin 2007; Cheesman et al. 2010; Kanther \& Rawls 2010, Ghanbari et al. 2015). Fish microbiome composition has been linked to diverse factors including host type (Ye et al. 2014; Givens et al. 2015, Hennersdorf et al. 2016), trophic ecology and diet (Bolnick et al. 2014a,b; Miyake et al. 2015; Sullam et al. 2015), and environmental conditions (e.g., salinity; Sullam et al. 2012; Schmidt et al. 2015).

The composition of the fish microbiome can also change significantly over an individual's lifespan (Bakke et al. 2015; Burns et al. 2015, Llewellyn et al. 2015). However, the timing, determinants, and magnitude of these shifts are unclear for most taxa, and likely highly variable among species with differing life histories. On coral reefs, for example, $>90 \%$ of fish species undergo a dispersing or planktonic stage as either larvae or juveniles, followed by an adult phase marked by settlement into a constrained territory on the reef (Leis et al. 1991). For such species, microbiome structure is hypothesized to be shaped by a combination of factors that co-associate with host life stage, including diet shifts, immune system and GI tract development, and differences in the composition of the external microbial community between pre- and post-settlement habitats.

Comparing reef fish microbiomes over developmental stages will help identify shifts in the contribution of the microbiome to host health and behavior, thereby helping reach a 
84 holistic understanding of reef ecology. Collectively, coral reefs harbor over 2500 fish species engaged in a complex web of interactions, including predation, herbivory, corallivory, and symbiosis (Bellwood et al. 2004; Allen 2014). These interactions together modulate material and energy transport and ecosystem structuring on coral reefs, with important consequences for reef-building corals that rely on fish waste for nutrients, or fish herbivory to limit competition with benthic macroalgae (Mumby et al. 2006; Burkepile \& Hay 2008; McCauley et al. 2010). Such interactions may also be important vectors for moving microbes between reef habitats. A handful of studies have characterized gut microbiomes of coral reef fish, identifying a role for both diet type and host identity in shaping microbiome composition (Smriga et al. 2010, Miyaki et al. 2015). However, the microbiomes of the vast majority of reef fishes, including some of the most abundant and ecologically relevant taxa, remain uncharacterized.

Damselfish (Pomacentridae) and cardinalfish (Apogonidae) are among the most diverse and abundant families of reef fishes and exhibit similar ecological strategies. Species within these families occupy critical positions in reef food webs as generalist planktivorous consumers, subsisting on a variety of algae, plankton, and benthic invertebrates (Emery et al. 1973, Emery et al. 1980, Marnane and Bellwood, 2002). These fish also constitute major fractions of the diet of larger piscivorous reef fish (BeukersStewart and Jones, 2004). Most species of damselfish and cardinalfish spend their first 12 to 35 days of life as members of the off-reef plankton community before settling back onto the reef as juveniles (Wellington and Victor, 1989, Leis et al. 1991, Leis et al. 1996). Postsettlement, damselfishes (including members of the Chromis, Pomacentrus, and Dascyllus genera) occupy distinct microhabitats using various types of coral for habitat and cover 
107 (Wilson et al. 2008). Many Pomacentrids are highly territorial and influence turf algae

108

109

110

111

112

113

114

115

116

117

118

119

120

121

122

123

124

125

126

127

128

composition through grazing (Hinds, 1987, Klumpp and Polunin, 1989). Apogonids also occupy coral microhabitats during the day when they are mostly inactive but leave coral cover at night to feed throughout the water column (Gardiner and Jones, 2005). Fish

species of the Apogonidae often dominate nocturnal planktivore assemblages (Manane and Bellwood, 2002). In this study, we quantified microbiome taxonomic composition (16S rRNA gene diversity) in whole guts from replicate individuals from ten species of damselfish and two species of cardinalfish (Table S1). We focused on comparisons between pre-settlement planktonic larvae and post-settlement individuals (juveniles through to adults) to determine whether microbiome composition varied between ontogenetic stages and, if so, whether this variation was related to differences in the microbial composition of the surrounding water column.

\section{MATERIALS AND METHODS}

\section{Sample collection}

Fishes were collected over a 3-4 day period from the fringing reefs surrounding Lizard Island, Australia (14 $\left.{ }^{\circ} 40.08^{\prime} \mathrm{S} 145^{\circ} 27.34^{\prime} \mathrm{E}\right)$ in February 2014 . Water depths at collection sites were approximately 5-10 meters. Larval, pre-settlement individuals (8-16 mm total length, Table S1) were defined as samples collected from floating light traps deployed overnight at a single site. These traps sampled the upper meter of the water column above the reef. Post-settlement stage juveniles/adults (14-36 mm total length, Table S1) were individuals hand-collected on SCUBA at depth from nearby reefs using dip nets. Post-settlement fish in this study were likely sexually immature (juveniles) and 
129 recently settled, given their small size (sexual maturity in most Pomacentrids typically 130 occurs at lengths $>60 \mathrm{~mm}$, Schmale et al. 1986, Kavanaugh, 2000). Net capture of settled

131 fish followed mild sedation with a clove oil/ethanol mixture dispensed via spray bottle. All 132 fish were euthanized by immersion in a seawater-ice slurry combined with an overdose of 133 clove oil and stored in ethanol for further analysis. Water column samples $(\mathrm{n}=11)$ were 134 collected on SCUBA at the same depth and location of post-settlement fish collection sites 135 and the light trap site using sterile plastic 1L bottles. Bottles were first opened within the 136 water column to ensure collection at the desired location and prevent contamination.

137 Microbial biomass in the sampled water was concentrated onto $0.2 \mu$ m Polyvinylidene 138 Flouride (PVDF) filters through filtration. Filters were immediately placed in ethanol in cryovials and stored at room temperature until processing. Fish were identified to the lowest possible taxonomic unit, typically either genus or species, using Indo-Pacific reef

141 fish field guides based on morphology. In total, 49 pre-settlement individuals were sampled (Table S1), including individuals of the damselfish Pomacentrus moluccensis $(\mathrm{n}=4)$, P. chrysurus $(\mathrm{n}=4), P$. nagasakiensis $(\mathrm{n}=4), P$. amboinensis $(\mathrm{n}=4), P$. $\operatorname{wardii}(\mathrm{n}=4), P$. bankanensis $(\mathrm{n}=4)$, P. coelestis $(\mathrm{n}=4)$, Dascyllus aruanus $(\mathrm{n}=3)$ and an unidentified Chromis 145 species $(n=7)$. Two species of pre-settlement stage cardinalfish, Ostorhinchus doederleini $146(n=4)$ and an unidentified Apogon species ( $n=7)$, were also collected. A total of 24 post147 settlement individuals were sampled (Table S1), including individuals of 5 species of 148 damselfish (P. moluccensis $(\mathrm{n}=6), P$. chrysurus $(\mathrm{n}=3)$, A. polyacanthus $(\mathrm{n}=3)$, Dascyllus aruanus $(\mathrm{n}=5)$ and an unidentified Chromis sp. $(\mathrm{n}=3))$ and 1 cardinalfish $(0$. doederleini $150(n=4))$. Note that the individuals of the unidentified Chromis species (collected both pre 151 and post-settlement) were almost certainly either Chromis viridis or Chromis atripectoralis, 
152 both of which are similar ecologically and closely related. All research was reviewed and 153 conducted under the guidelines of Georgia Tech IACUC \#A14063 and Great Barrier Reef 154 Marine Park Authority collection permits G13.36166.1 and animal ethics permits A1920. 155 These methods were approved by Georgia Tech IACUC and Great Barrier Reef Marine Park 156 Authority for use in this study.

\section{DNA extractions}

Whole fish samples were removed from storage containers and rinsed thoroughly with fresh, filter-sterilized ethanol to remove (potentially) surface-attached microbes. As dissection of only the intestinal contents was not possible due to the small size of most presettlement individuals, whole gut contents (stomach + intestines) were excised by dissection with a sterile razor from each individual. Excised contents were placed in a sterile $1.5 \mathrm{ml}$ centrifuge tube and frozen until extraction. Bulk DNA was extracted from gut contents using the Qiagen DNeasy blood and tissue kit according to manufacturer instructions. To process water samples, each collection filter was transferred from ethanol into a clean, $1.5 \mathrm{ml}$ centrifuge tube. The ethanol remaining in the original storage tube was

167 vacuum-filtered onto a new $0.2 \mu \mathrm{m}$ PVDF filter, which was then dried at room temperature and pooled with the initial collection filter. DNA was extracted from filters using a phenol:chloroform method. Briefly, cells were lysed by adding lysozyme ( $2 \mathrm{mg}$ in $40 \mu \mathrm{l}$ of lysis buffer per sample) directly to the pooled filters, capping, and incubating for $45 \mathrm{~min}$ at

$17137^{\circ} \mathrm{C}$. Proteinase $\mathrm{K}(1 \mathrm{mg}$ in $100 \mu \mathrm{l}$ lysis buffer, with $100 \mu \mathrm{l} 20 \% \mathrm{SDS})$ was added and

172 samples incubated for an additional 2 hours at $55^{\circ} \mathrm{C}$. The lysate was removed, and DNA

173 was extracted once with phenol:chloroform:isoamyl alcohol (25:24:1) and once with 
174 chloroform:isoamyl alcohol (24:1). Extracted DNA was concentrated by spin dialysis using

175 Ultra-4 (100 kDa, Amicon) centrifugal filters and stored frozen.

\section{$176 \quad$ PCR amplification and sequencing}

High-throughput sequencing of dual-indexed PCR amplicons spanning the V3-V4 hypervariable regions of the $16 \mathrm{~S}$ rRNA gene was used to assess gut microbiome taxonomic composition. Amplicons were synthesized using Platinum $®$ PCR SuperMix (Life Technologies) with primers F515 (5'-GTGCCAGCMGCCGCGGTAA-3') and R806 (5'include sample-specific barcodes and Illumina sequencing adapters according to Kozich et al. (2013). Ten nanograms of starting DNA was used as template for each PCR reaction. Amplification was performed using denaturation at $94^{\circ} \mathrm{C}(3 \mathrm{~min})$, followed by 30 cycles of denaturation at $94^{\circ} \mathrm{C}(45 \mathrm{sec})$, primer annealing at $55^{\circ} \mathrm{C}(45 \mathrm{sec})$, primer extension at $72^{\circ} \mathrm{C}$ (90 sec), and a final extension at $72^{\circ} \mathrm{C}$ for $10 \mathrm{~min}$. Amplicon products were verified using gel electrophoresis, purified using Diffinity RapidTip2 PCR purification tips (Diffinity Genomics, NY), and quantitated fluorometrically using the Qubit (Life Technologies). Amplicons from different samples were pooled at equimolar concentrations and sequenced on an Illumina MiSeq using a 500 cycle kit with 30\% PhiX added to increase sequence

191 diversity. All raw sequences are available in the NCBI Sequence Read Archive under 192 BioProject ID PRJNA290348.

\section{Sequence Analysis}


196 using Trim Galore (http://www.bioinformatics.babraham.ac.uk/projects/trim_galore/).

197 Paired-end reads were then merged using FLASH (Magoč \& Salzberg 2011), with an 198 average read length of 250, and a fragment length of 300. Merged reads were analyzed 199 using the QIIME pipeline (Caporaso et al. 2010). In QIIME, chimeric sequences were 200 identified using USEARCH (Edgar, 2010) and removed from the input dataset. Merged, 201 non-chimeric sequences were clustered into Operational Taxonomic Units (OTUs) at 97\% 202 sequence similarity using open-reference picking with the UCLUST algorithm (Edgar 203 204 205 206 207 208 209 2010). Singleton OTUs (those represented by only one sequence read in the combined dataset) were also removed at this step. Taxonomy was assigned to each OTU by comparison with the Greengenes database 13_5 release (DeSantis et al. 2006).

Cyanobacterial and chloroplast sequences were manually removed from the OTU tables as these sequences can be assumed to reflect non-host-associated taxa, potentially those brought into the gut through food passage. Selected OTUs were queried via BLASTN against the NCBI-nr database to identify closest relatives. rarified OTU table was used in downstream analysis. A Bonferroni-corrected ANOVA was used to identify microbial families significantly enriched in pre vs post-settlement 213 individuals, with family composition data expressed as percentage of total reads. Alpha 214 and beta diversity statistics for pre- and post-settlement individuals were calculated in 215 QIIME using the core_diversity_analyes.py command. The unweighted Unifrac metric was used to conduct principal coordinates analysis to visualize beta diversity. Significant 217 differences in beta diversity were identified using a two-sided t-test (Bonferroni218 corrected). Core microbiome analysis was performed in QIIME using the 
219 compute_core_microbiome.py script to identify individual OTUs shared by at least 70\% of

220 all individuals per sample grouping (all pre-settlement individuals vs. all post-settlement

221 individuals). This script was also used to estimate the average number of OTUs shared

222 between random pairs of individuals from each life stage, based on 100 random iterations

223 per life stage. Indicator analysis was performed with the indicspecies package in R to

224 identify genera (indicator taxa) significantly enriched according to life stage, taking into

225 consideration both the extent to which an OTU is exclusive to a life stage (A component), as

226 well as the relative frequency at which the OTU occurs in all individuals within a stage (B

227 component)(Dufresne and Legendre 1997; Fortunato et al. 2013). Only those taxa

228 occurring in more than half of all samples (B component $>0.5$ ) and for which permutation

229 testing yielded p-values $<0.05$ are included in the output. Indicator values range from 0 to

2301 with higher values reflecting stronger relationships between indicator taxa and the tested

231 sample groupings (pre vs. post-settlement).

\section{RESULTS AND DISCUSSION}

\section{General microbiome characteristics}

A total of 49 pre-settlement and 24 post-settlement individuals representing ten

235 Pomacentridae species and two Apogonidae species were collected from Lizard Island, 236 Australia. Of these, five species - the pomacentrids Pomacentrus moluccensis, P. chrysurus, 237 Dascillus aruanus, and an unidentified Chromis sp. (either C. viridis or C. atripectoralis) and 238 the apogonid Ostorhinchus doederleini - were represented by both pre- and post-settlement 239 individuals, with the remaining species represented only in the pre-settlement sample set $240(n=6$ species $)$ or only in the post-settlement set $(n=1)$. 
A total of 3,503,605 16S rRNA gene sequences were obtained after quality control

242 filtering (average: 41,709 per sample; range: 4262-238,858). After rarefaction, OTU counts

243 per sample were highly variable, from 44 to 557 OTUs, with averages of 163 ( \pm 59 standard

244 deviation (SD)) and $245( \pm 102$ SD) for pre- and post-settlement stages, respectively. As

245 observed in other fish species (Spanggaard et al. 2000; Al-Harbi \& Naim Uddin 2004;

246 Martin-Antonio et al. 2007; Sullam et al. 2012; Xing et al. 2013), Pomacentrid and Apogonid

247 gut microbiomes were dominated by Gammaproteobacteria of the

248 Pseudoaltermonadaceae, Endozoicimonaceae, Vibrionaceae, and Shewanellaceae, with

249 these Families constituting $80 \%( \pm 10.3 \mathrm{SD})$ and $67 \%( \pm 6.7 \mathrm{SD})$ of all sequence reads in pre-

250 and post-settlement fishes, respectively (Figure S1), although key differences in the relative 251 abundance of microbial families were also evident (discussed below, Table 1).

It is important to note that our data do not differentiate communities based on

253 location in the GI tract, as the small size of individuals prohibited separation of intestine

254 from stomach contents. Thus, we cannot distinguish between resident gut microbiome

255 members, which might be relatively more common in the intestine, versus members

256 derived from food contents or passively from seawater intake, which might be relatively

257 enriched in the stomach. Both host-adapted as well as transient microbiome members may

258 nonetheless exert effects on host health, as either symbionts or potentially as inocula for

259 resident populations. However, gut microbiome composition (weighted Unifrac;

260 Pomacentridae + Apogonidae combined) of both pre- and post-settlement stages differed

261 significantly from that of the surrounding seawater $(\mathrm{p}=0.028$; Figure 1), which was instead

262 enriched in Gammaproteobacteria of the Halomonadaceae family, Alphaproteobacteria,

263 and Bacteroidetes (Figure S2). Moreover, microbiome composition did not differ 
264 significantly between water collection sites (Figure S3), suggesting fine-scale variation in

265 local environments alone should not influence microbiome composition. The microbiome

266 composition data also suggests minimal effect of source water on gut microbiome

267 structure.

\section{Microbiome diversity and composition}

Microbiomes showed a general trend toward greater complexity following settlement, although this trend was variable among species. The phylogenetic composition

271 of the combined (Pomacentrid + Apogonid) microbiomes changed significantly from pre- to

272 post-settlement groups (weighted Unifrac metric; $\mathrm{p}=0.028$ ), with pre-settlement

273 microbiomes showing less intra-individual variation compared to those of post-settlement

274 fish (Figure 1) and overall lower phylogenetic diversity (PD) (average: $20.3 \pm 7$ SD, versus

$27528.7 \pm 12$ SD post-settlement; $\mathrm{p}=0.001$, t-stat $=3.5$; Figure 2). Both pre- and post-

276 settlement microbiomes exhibited substantially lower PD than the surrounding water

277 column community (PD: $79.4 \pm 23.5$ SD; $p=0.001$ ). Of the five species for which both pre-

278 and post-settlement samples were available, three - Chromis sp., O. doederleini, and D.

279 aruanus - exhibited significantly higher PD post-settlement (Figure 3, p=0.001). Greater

280 microbiome diversity with age has been observed in other fish species, with suggested

281 linkages to increases in diet complexity (Bolnick et al. 2014a,b; Miyake et al. 2015; Sullam

282 et al. 2015), or potentially to differentiation of the GI tract into distinct niches with

283 development. In contrast, elevated microbiome diversity in early life was observed in $P$.

284 chrysurus and P. moluccensis (Figure 3, $\mathrm{p}=0.001$ ), consistent with data from lab-reared

285 zebrafish (Stephens et al 2015). This pattern suggests that pre-settlement microbiomes in 
286 these species are influenced primarily by transient associations with bacteria from the

287 exterior environment or by higher diet complexity at the planktonic stage. As an individual

288 matures, its microbiome may become more specialized in response to diverse factors,

289 including diet shifts, immune system development, physiological and chemical changes

290 along the GI tract, or decreased connectivity with the external environment. Indeed,

291 species-specific microhabitat usage (i.e., selection of distinct coral types by different

292 species) has been observed in some of the hosts examined here, including P. moluccensis

293 and P. nagasakiensis. However, all settled hosts in our dataset are assumed to be generalist

294 planktivores with fairly similar post-settlement diets based on prior work (Emery 1973,

295 Emery and Thresher, 1980, Marnane and Bellwood, 2002). Although this study does not

296 allow us to quantify the influence of each of the factors discussed above on developmental

297 shifts in microbiome composition, our data, combined with results from prior studies,

298 suggest that microbiome diversity is dynamic over life stages and assembly processes vary

299 on a per-species basis.

Key microbial taxa differed in abundance between pre- and post-settlement

301 microbiomes (Table 1), although microbiome composition was relatively consistent within

302 hosts per age group (Figure S3). At the microbial family level, pre-settlement microbiomes

303 were significantly enriched (>70-fold) in bacteria of the Endozoicimonaceae, while settled

304 fish harbored over 2-fold higher median abundances of the abundant Vibrionaceae and an

30580 -fold enrichment of planctomycetes of the Pirellulaceae (Table 1). Differences in the

306 relative abundance of microbes at the family level did not appear to be driven by a single

307 host. For example, all pre-settlement individuals were enriched in bacteria of the

308 Endozoicomonaceae compared to post-settlement hosts (Figure S4). At the microbial 
309 genus level, both life stages were marked by sets of indicator taxa (Table 2). Indicator taxa

310 represent individual OTUs showing significant enrichment (as a percent of total sequence

311 reads) in one life stage vs. the other according to permutation testing $(\mathrm{p}<0.05$, Dufresne

312 and Legendre 1997; Fortunato et al. 2013). The number of indicators was considerably

313 higher for settled fish (38) compared to larvae (5; Table 2), consistent with the increase in

314 diversity associated with post-settlement, perhaps reflective of an overall expansion in

315 microbial niche breadth as discussed above. The marine bacterial genera Kordia

316 (Flavobacteriia) and Halomonas (Gammaproteobacteria, Oceanospirillales) were the

317 strongest indicators of pre-settlement stage (Table 2), followed by members of the

318 Arcobacter (Epsilonproteobacteria, Campylobacterales), Oceanospirillum

319 (Gammaproteobacteria, Oceanospirillales), and Idiomarina (Gammaproteobacteria,

320 Alteromonadales), all taxa common to the marine environment but not often observed in

321 fish microbiomes. Pre-settlement enrichment implicates these taxa as important during

322 early development, more successful at colonizing and growing in young fishes, or

323 commonly associated with pre-settlement food sources. Indicators of post-settlement

324 spanned a wide phylogenetic breadth, with a number classifiable only to the order or

325 family level, and the strongest indicators including diverse members of the

326 Gammaproteobacteria (Vibrionaceae, Portiera), Firmicutes (Epulopiscium),

327 Alphaproteobacteria (Kiloniellales, Hyphomicrobiaceae), Verrucomicrobia

328 (Coraliomargarita), and Planctomycetes (Pirellulaceae) (Table 2). Enrichment of these taxa

329 in fully developed, settled fish suggests the host GI tract as a specific niche for members of

330 these groups.

331 Comparison of the core microbiome between pre and post-settlement individuals 
Although egg-tending behavior is common in many pomacentrids, fish are presumed sterile at birth and fish gut microbiome is assumed to be inoculated primarily

334 from the environment and via food items early in life (Nayak 2010). If the pre-settlement, pelagic diet is similar across species, it is reasonable to predict that larval individuals of different fish species will share a greater number of microbial taxa (i.e., larger core microbiome). The core microbiome might then be expected to shrink post-settlement as species adapt to specific diets and microhabitats. We explored this prediction in two ways. First, we determined the average number of OTUs shared between randomly sampled pairs of pre-settlement individuals compared to post-settlement individuals. Contrary to our expectation, the average count of shared OTUs did not vary with life stage (22.8 vs 23.2 for pre- and post-settlement, respectively). Second, we compared the richness and composition of the core microbiome between life stages, following normalization to a 344 uniform sample size (\# of host individuals) per stage. Consistent with a recent analysis of microbiomes from 15 coastal fish species (Givens et al. 2015), no single microbial OTU was 346 present in all individuals of either group (pre or post) in our study. Contrary to our 347 prediction, the richness of the core microbiome was similar for both pre and post348 settlement stages; for example, 17 OTUs were shared across $70 \%$ of pre-settlement 349 individuals, compared to 15 for post-settlement (Figure 4). Furthermore, many of the same 350 OTUs were present in the core microbiomes identified at each stage. For example, of the 351 OTUs occurring in 70\% of total microbiome samples (pre- and post combined), 12 (of 16 total) were present in both the pre- and post-settlement core sets (70\% threshold) when

353 evaluated separately (Figure 4), indicating conservation of a subset of key microbial 354 members across settlement. Together, these results suggest processes affecting assembly 
355 and diversity of the core microbiome, when defined at the OTU level, are relatively constant

356 from pre- to post-settlement.

Many of these core OTUs were absent from or at much lower abundances in seawater samples (with the exception of 3 OTUs), indicating selective accumulation in the fish gut (Figure 4). Notably a single OTU with high sequence similarity to Vibrio harveyi (Vibrionaceae, Genbank accession KX380754.1) comprised an average of $18-20 \%$ of the total sequence reads in both pre- and post-settlement fish, but only $2 \%$ of the seawater community (Figure 4). Vibrios are often described as opportunistic pathogens (Karunasagar et al. 1994; Austin \& Zhang 2006). For example, metagenome sequences related to Vibrio species, including $V$. harveyi, from the guts of farmed adult turbot were enriched in genes encoding potential virulence functions (Xing et al. 2013). However, the wide distribution of $V$. harveyi in healthy marine hosts, observed here and in other studies

367 of diverse invertebrates and fish (Onarheim et al. 1994; Guerrero-Ferreira et al. 2013;), 368 suggests that the primary niche of this bacterium may be commensal or even mutualistic 369 with the host, potentially with a role in protein degradation and digestion (Ray et al. 2012).

370 Interestingly, the Vibrionaceae family as a whole (multiple OTUs) was over twice as

371 abundant in post-settlement fish (Table 1) and therefore may be more typical of mature gut 372 microbiome communities.

374 between life stages. The 16 taxa detected in $70 \%$ of all microbiome samples, a core set 375 dominated by OTUs belonging to the Gammaproteobacteria (Figure 4), constituted $\sim 60 \%$ 376 of the total gut microbiome sequence reads in pre-settlement fish but only 25\% in settled 
377 fish, indicating that these OTUs may be important early in life. Notably, OTUs closely

378 related to Shewanella putrafaciens (Genbank accession KP967510.1) and to an uncultured

379 bacterium of the family Endozoicomonaceae (Genbank accession LN626318.1) constituted

3808 and $18 \%$ of the pre-settlement microbiome, respectively, but less than $1 \%$ of the post-

381 settlement community (Figure 4). To our knowledge, this is the first report of

382 Endozoicomonaceae occupying a large proportion of the fish gut microbiome. Bacteria of

383 this family, within the widely distributed Oceanospiralles group, exhibit diverse

384 heterotrophic metabolisms (Neave et al. 2014) and are commonly identified as symbionts

385 in marine invertebrates (Bayer et al. 2013a; Bayer et al. 2013b; Forget \& Juniper 2013;

386 Nishijima et al. 2013; Beinart et al. 2014; Hyun et al. 2014), suggesting invertebrate prey as

387 a potential vector of transport into the fish microbiome. The functional properties and 388 potential for long-term residency of these bacteria in reef fishes remain to be verified. In

389 contrast, Gammaproteobacteria of the genus Shewanella,have been detected widely in fish.

390 Indeed, Shewanella putrefaciens, the species most closely related (97\%) to the core OTU in

391 this study, has been used as a probiotic to increase growth and pathogen resistance in 392 juvenile sole (Lobo et al. 2014).

Other members of the core OTU set spanned diverse bacterial divisions, but

394 occurred at lower abundances (Figure 4). These included members of genera containing

395 known fish pathogens, such as Photobacterium (Chabrillon et al. 2005), Pseudoalteromonas

396 (Pujalte et al. 2004), Pseudomonas (Wakabayashi et al. 1996), and Halomonas (Austin

397 2005). However, these groups also contain potentially beneficial members, as certain

$398 \quad$ Pseudoalteromonas and Alteromonas strains can inhibit bacterial pathogens in fish

399 (Gatesoupe 1999) and Photobacterium species are known bioluminescent symbionts in 
400 diverse fish hosts (Ruby \& Nealson 1976; Ast et al. 2007). Core OTUs also included a

401 Chromatiales-affiliated taxon with 100\% similarity to the uncultured gill symbiont of

402 Ifremeria nautilei (Beinart et al. 2013, Genbank accession KF780855.1), a member of the

403 Kordia genus resembling a heterotrophic isolate from the gut of marine polychaetes (Choi

404 et al. 2011, Genbank accession NR_117471.1), and Salinivibrio costicola, a halotolerant,

405 facultatively anaerobic bacterium first isolated from a hypersaline pond (Huang et al.

406 2000). Three OTUS matching marine Rhodobacteraceae, a broadly distributed aquatic

407 group that has also been detected in reef surgeonfish (Miyake et al. 2015), were also

408 prevalent across samples. However, two of these OTUs were more abundant in water

409 samples, suggesting these taxa may be transient members of the gut community. Together,

410 these data identify a relatively species-poor (e.g., 16 OTUs at 70\%) but abundant (35-65\%

411 of total $16 \mathrm{~S}$ sequences) core microbiome across the damselfish and cardinalfish sample set,

412 including potentially pathogenic or beneficial bacteria, and a subset of core OTUs (12 of 16)

413 that persist across pre- and post-settlement life stages. Persistence over development may

414 be an important indicator of commensal or mutualistic taxa ubiquitous to reef fish.

415 Conclusion

These results describe a diverse gut microbiome in two abundant reef fish families

417 and highlight the importance of life stage in structuring microbiome composition. A trend

418 toward greater microbiome diversity in settled (older) individuals was observed in the

419 pooled dataset, potentially explained by the hypothesis that pre-settlement fish of diverse

420 species are more similar to each other physiologically compared to adults, occupy the same

421 niche (pelagic zone), and acquire gut microbes from a common environmental pool, 
422 perhaps due to similarities in diet. These factors could homogenize the pre-settlement

423 microbiome across diverse host species, with microbiomes diversifying after fish settle on

424 the reef and transition to adult feeding roles. However, this pattern is not uniform across

425 host species, suggesting a need for discretion in concluding general trends in microbiome

426 succession over development. Our data also identify core microbes common to pre- and

427 post-settlement fish of several host species. Persistence of these microbes over major life

428 transitions, regardless of variable trends in bulk microbiome complexity, may implicate

429 these microbes as particularly important to host health and physiology. Differences in

430 microbiome assembly between pre and post-settlement fish are likely driven by a

431 combination of factors, including physiological changes associated with development,

432 changes in diet and potentially feeding frequency, and varying connectivity with microbes

433 from the external environment. More research is needed to disentangle the relative

434 contributions of these determinants over the settlement transition.

435 Acknowledgements

436 We thank the staff of Lizard Island Research Station for logistical support. 


\section{References}

1. Al-Harbi, A. H., \& M. Naim Uddin. (2004). Seasonal variation in the intestinal bacterial flora of hybrid tilapia (Oreochromis niloticus $\times$ Oreochromis aureus) cultured in earthen ponds in Saudi Arabia. Aquaculture, 229, pp. 37-44.

2. Allen, G. R. (2014). Review of Indo-Pacific coral reef fish systematics: 1980 to 2014. Ichthyological Research, 62(1), pp. 2-8.

3. Angert ER, Clements KD, \& Pace, NR (1993). The Largest Bacterium. Nature, 362, pp. 239-241.

4. Austin, B. (2005). Bacterial pathogens of marine fish. In Oceans and health: pathogens in the marine environment, pp. 391-413, Springer US.

5. Austin, B., \& Zhang, X. H. (2006). Vibrio harveyi: a significant pathogen of marine vertebrates and invertebrates. Letters in applied microbiology, 43(2), pp. 119-124.

6. Ast, J. C., Cleenwerck, I., Engelbeen, K., Urbanczyk, H., Thompson, F. L., De Vos, P., \& Dunlap, P. V. (2007). Photobacterium kishitanii sp. nov., a luminous marine bacterium symbiotic with deep-sea fishes. International journal of systematic and evolutionary microbiology, 57(9), pp. 2073-2078.

7. Backhed, F., Ley, R., Sonnenburg, J., Peterson, D., \& Gordon, J. (2005). Host-Bacterial Mutualism in the Human Intestine. Science, 307, pp. 1915-1920.

8. Bakke, I., Coward, E., Andersen, T., \& Vadstein, O. (2015). Selection in the host structures the microbiota associated with developing cod larvae (Gadus morhua). Environmental microbiology, 17(10), pp. 3914-3924.

9. Bano, N., A. Derae Smith, W. Bennett, L. Vasquez, \& J. T. Hollibaugh. (2007). Dominance of Mycoplasma in the guts of the Long-Jawed Mudsucker, Gillichthys mirabilis, from five California salt marshes. Environmental Microbiology 9, pp. 26362641.

10. Bates, J.M., Mittge, E., Kuhlman, J., Baden, K. N., Cheesman, S. E., \& Guillemin, K. (2006). Distinct signals from the microbiota promote different aspects of zebrafish gut differentiation. Dev Biol 297, pp. 374-386.

11. Bates J. M., Akerlund, J., Mittge, E., \& Guillemin, K. (2007). Intestinal alkaline phosphatase detoxifies lipopolysaccharide and prevents inflammation in zebrafish in response to the gut microbiota. Cell Host Microbe 2, pp. 371-382.

12. Bayer, T., Neave, M. J., Alsheikh-Hussain, A., Aranda, M., Yum, L. K., Mincer, T., ... \& Voolstra, C. R. (2013a). The microbiome of the Red Sea coral Stylophora pistillata is dominated by tissue-associated Endozoicomonas bacteria. Applied and environmental microbiology, 79(15), pp. 4759-4762.

13. Bayer T, Arif C, Ferrier-Pagès C, Zoccola D, Aranda M, Voolstra CR. (2013b). Bacteria of the genus Endozoicomonas dominate the microbiome of the Mediterranean gorgonian coral Eunicella cavolini. Mar. Ecol. Prog. Ser. 479, pp. 75-84.

14. Beinart, R. A., Nyholm, S. V., Dubilier, N., \& Girguis, P. R. (2014). Intracellular Oceanospirillales inhabit the gills of the hydrothermal vent snail Alviniconcha with chemosynthetic, $\gamma$-Proteobacterial symbionts. Environmental microbiology reports, $6(6)$, pp. 656-664.

15. Bellwood DR, Hughes TP, Folke C, \& Nyström M. (2004). Confronting the coral reef crisis. Nature. 429 , pp. 827-833. 
16. Beukers-Stewart, B. D., \& Jones, G. P. (2004). The influence of prey abundance on the feeding ecology of two piscivorous species of coral reef fish. Journal of Experimental Marine Biology and Ecology, 299(2), pp. 155-184.

17. Bolnick DI, Snowberg LK, Hirsch PE, Lauber CL, Knight R, Caporaso JG, \& Svanbäck R. (2014a). Individuals' diet diversity influences gut microbial diversity in two freshwater fish (threespine stickleback and Eurasian perch. Ecol Lett., 17(8), pp. 979-87.

18. Bolnick, D. I., Snowberg, L. K., Hirsch, P. E., Lauber, C. L., Parks, B., Lusis, A. J., ... \& Svanbäck, R. (2014b). Individual diet has sex-dependent effects on vertebrate gut microbiota. Nature Communications, 5.

19. Bourne, D. G., Garren, M., Work, T. M., Rosenberg, E., Smith, G. W., \& Harvell, C. D. (2009). Microbial disease and the coral holobiont. Trends in microbiology, 17(12), pp. 554-562.

20. Brooker, R. M., Munday, P. L., \& Ainsworth, T. D. (2010). Diets of coral-dwelling fishes of the genus Gobiodon with evidence of corallivory. Journal of fish biology, 76(10), pp. 2578-2583.

21. Brooker, R. M., Munday, P. L., Chivers, D. P., \& Jones, G. P. (2015). You are what you eat: diet-induced chemical crypsis in a coral-feeding reef fish. Proceedings of the Royal Society of London B: Biological Sciences, 282, p. 1799.

22. Burkepile DE, \& Hay ME. (2008). Herbivore species richness and feeding complementarity affect community structure and function on a coral reef. Proceedings of the National Academy of Sciences, 105, p. 16201.

23. Burns, A.R., Zac Stephens, W., Stagaman, K., Wong, S., Rawls, J.F., Guillemin, K., \& Bohannan, B.J. (2015). Contribution of neutral processes to the assembly of gut microbial communities in the zebrafish over host development. ISME J, 10, pp. 655-664.

24. Caporaso, J. G., Kuczynski, J., Stombaugh, J., Bittinger, K., Bushman, F. D., Costello, E. K., ... \& Huttley, G. A. (2010). QIIME allows analysis of high-throughput community sequencing data. Nature methods, 7(5), pp. 335-336.

25. Caporaso, J. G., Lauber, C. L., Walters, W. A., Berg-Lyons, D., Lozupone, C. A., Turnbaugh, P. J., ... \& Knight, R. (2011). Global patterns of 16S rRNA diversity at a depth of millions of sequences per sample. Proceedings of the National Academy of Sciences, 108(Supplement 1), pp. 4516-4522.

26. Chabrillón, M., Rico, R. M., Balebona, M. C., \& Moriñigo, M. A. (2005). Adhesion to sole, Solea senegalensis Kaup, mucus of microorganisms isolated from farmed fish, and their interaction with Photobacterium damselae subsp. piscicida. Journal of fish diseases, 28(4), pp. 229-237.

27. Cheesman S. \& Guillemin K. (2007). We know you are in there: conversing with the indigenous gut microbiota. Res Microbiol 158, pp. 2-9.

28. Cheesman S. E., Neal, J. T., Mittge, E., Seredick, B. M., \& Guillemin, K. (2010). Microbes and Health Sackler Coloquiium: Epethelial cell proliferation in the developing zebrafish intestine is regulated by the Wnt pathway and microbial signaling via Myd88. Proc Natl Acad Sci. 108, pp. 4570-4577.

29. Chimetto, L. A., Cleenwerck, I., Thompson, C. C., Brocchi, M., Willems, A., De Vos, P., \& Thompson, F. L. (2010). Photobacterium jeanii sp. nov., isolated from corals and zoanthids. International journal of systematic and evolutionary microbiology, 60(12), pp. 2843-2848. 
30. Choi, A., Oh, H. M., Yang, S. J., \& Cho, J. C. (2011). Kordia periserrulae sp. nov., isolated from a marine polychaete Periserrula leucophryna, and emended description of the genus Kordia. International journal of systematic and evolutionary microbiology, 61(4), pp. 864-869.

31. Chung H, Pamp SJ, Hill JA, Surana NK, Edelman SM, Troy EB, Reading NC, Villablanca EJ, Wang S, Mora JR, Umesaki Y, Mathis D, Benoist C, Relman DA, \& Kasper DL. (2012). Gut immune maturation depends on colonization with a host-specific microbiota. Cell, 149(7), pp. 1578-93.

32. Clements KD, Angert ER, Montgomery WL, \& Choat JH. (2014). Intestinal microbiota in fishes: what's known and what's not. Molecular Ecology. 23, pp. 1891-1898.

33. Coates, D. (1980). Prey-size intake in humbug damselfish, Dascyllus aruanus (Pisces, Pomacentridae) living within social groups. The Journal of Animal Ecology, 49(1), pp. 335-340.

34. Cole, A. J., Pratchett, M. S., \& Jones, G. P. (2008). Diversity and functional importance of coral-feeding fishes on tropical coral reefs. Fish and Fisheries, 9(3), pp. 286-307.

35. Cole, A. J., Lawton, R. J., Wilson, S. K., \& Pratchett, M. S. (2012). Consumption of tabular acroporid corals by reef fishes: a comparison with plant-herbivore interactions. Functional Ecology, 26(2), pp. 307-316.

36. Cooper W. J., \& Westneat M. W. (2009). Form and function of damselfish skulls: rapid and repeated evolution into a limited number of trophic niches. BMC Evol. Biol. 9, p. 24.

37. DeSantis, T. Z., Hugenholtz, P., Larsen, N., Rojas, M., Brodie, E. L., Keller, K., ... \& Andersen, G. L. (2006). Greengenes, a chimera-checked 16S rRNA gene database and workbench compatible with ARB. Applied and environmental microbiology, 72(7), pp. 5069-5072.

38. DiGiulio, D. B., Romero, R., Amogan, H. P., Kusanovic, J. P., Bik, E. M., Gotsch, F., ... \& Relman, D. A. (2008). Microbial prevalence, diversity and abundance in amniotic fluid during preterm labor: a molecular and culture-based investigation. PloS one, 3(8), e3056.

39. DiGiulio DB. (2012). Diversity of microbes in amniotic fluid. Semin Fetal Neonatal Med pp. 17, pp. 2-11.

40. Dominguez-Bello, M. G., Costello, E. K., Contreras, M., Magris, M., Hidalgo, G., Fierer, N., \& Knight, R. (2010). Delivery mode shapes the acquisition and structure of the initial microbiota across multiple body habitats in newborns. Proceedings of the National Academy of Sciences, 107(26), pp. 11971-11975.

41. Dufrene, M., \& Legendre, P. (1997). Species assemblages and indicator species: the need for a flexible assymetrical approach. Ecological Monographs, 67, pp. 345-366.

42. Edgar, R.C. (2010) Search and clustering orders of magnitude faster than BLAST. Bioinformatics 26, pp. 2460-2461.

43. Emery, A. R. (1973). Comparative ecology and functional osteology of fourteen species of damselfish (Pisces: Pomacentridae) at Alligator Reef, Florida Keys. Bulletin of Marine Science, 23(3), pp. 649-770.

44. Emery, A. R. \& Thresher, R. E. (Eds) (1980). Biology of the damselfishes. Bulletin of Marine Science 30, pp. 145-328.

45. Forget NL, \& Kim Juniper S. (2013). Free-living bacterial communities associated with tubeworm (Ridgeia piscesae) aggregations in contrasting diffuse flow hydrothermal vent habitats at the Main Endeavour Field, Juan de Fuca Ridge. MicrobiologyOpen 2, pp. 259-275. 
46. Fortunato, C. S., Eiler, A., Herfort, L., Needoba, J. A., Peterson, T. D., \& Crump, B. C. (2013). Determining indicator taxa across spatial and seasonal gradients in the Columbia River coastal margin. The ISME journal, 7(10), pp. 1899-1911.

47. Franchini, P., Fruciano, C., Frickey, T., Jones, J. C., \& Meyer, A. (2014). The gut microbial community of Midas Cichlid fish in repeatedly evolved Limnetic-Benthic species pairs. PloS one, 9(4), e95027.

48. Funkhouser, L. J., \& Bordenstein, S. R. (2013). Mom knows best: the universality of maternal microbial transmission. PLoS biology, 11(8), e1001631.

49. Ganesh, S., Parris, D.J., DeLong, E.F., \& Stewart, F.J. (2014). Metagenomic analysis of size-fractionated picoplankton in a marine oxygen minimum zone. ISME J 8, pp. 187211.

50. Gardiner, N. M., \& Jones, G. P. (2005). Habitat specialisation and overlap in a guild of coral reef cardinalfishes (Apogonidae). Marine Ecology Progress Series, 305, pp. 163175.

51. Gatesoupe, F. J. (1999). The use of probiotics in aquaculture. Aquaculture, 180(1), pp. 147-165.

52. Ghanbari, M., Kneifel, W., \& Domig, K. J. (2015). A new view of the fish gut microbiome: advances from next-generation sequencing. Aquaculture, 448, pp. 464-475.

53. Gill SR, Pop M, Deboy RT, Eckburg PB, Turnbaugh PJ, Samuel BS, Gordon JI, Relman DA, Fraser-Liggett CM, Nelson KE (2006). Metagenomic analysis of the human distal gut microbiome. Science 312, pp. 1355-1359.

54. Givens, C. E., Ransom, B., Bano, N., \& Hollibaugh, J. T. (2015). Comparison of the gut microbiomes of 12 bony fish and 3 shark species. Marine Ecology Progress Series, 518, pp. 209-223.

55. Glad T, Kristiansen V, Nielsen K, Brusetti L, Wright AD, \& Sundset M. (2010). Ecological characterisation of the colonic microbiota in Arctic and sub-Arctic seals. Microb. Ecol. 60, pp. 320-330.

56. Gourlay, R. N., WYLD, S. G., \& Leach, R. H. (1977). Mycoplasma alvi, a new species from bovine intestinal and urogenital tracts. International Journal of Systematic Bacteriology, 27(2), pp. 86-96.

57. Gray, M. A., Stone, R. P., McLaughlin, M. R., \& Kellogg, C. A. (2011). Microbial consortia of gorgonian corals from the Aleutian islands. FEMS microbiology ecology, 76(1), pp. 109-120.

58. Greenblum, S., Turnbaugh, P., \& Borenstein, E. (2012). Metagenomic systems biology of the human gut microbiome reveals topological shifts associated with obesity and inflammatory bowel disease. Proc. Natl. Acad. Sci. 109, pp. 594-599.

59. Grutter, A. S. (2002). Cleaning symbioses from the parasites' perspective. Parasitology, 124(07), pp. 65-81.

60. Guerrero-Ferreira R, Gorman C, Chavez AA, Willie S, \& Nishiguchi MK, (2013). Characterization of the bacterial diversity in Indo-West Pacific loliginid and sepiolid squid light organs. Microb Ecol., 65(1), pp. 214-26.

61. Hamdi, C., Balloi, A., Essanaa, J., Crotti, E., Gonella, E., Raddadi, N., ... \& Cherif, A. (2011). Gut microbiome dysbiosis and honeybee health. Journal of applied entomology, 135(7), pp. 524-533. 
62. Hehemann, J. H., Correc, G., Barbeyron, T., Helbert, W., Czjzek, M., \& Michel, G. (2010). Transfer of carbohydrate-active enzymes from marine bacteria to Japanese gut microbiota. Nature, 464(7290), pp. 908-912.

63. Hehemann, J. H., Kelly, A. G., Pudlo, N. A., Martens, E. C., \& Boraston, A. B. (2012). Bacteria of the human gut microbiome catabolize red seaweed glycans with carbohydrate-active enzyme updates from extrinsic microbes. Proceedings of the National Academy of Sciences, 109(48), pp. 19786-19791.

64. Heijtz, R., Wang, S., Anuar, F., Qian, Y., Björkholm, B., Samuelsson, A., Hibberd, M., Forssberg, H., \& Pettersson, S. (2011). Normal gut microbiota modulates brain development and behavior. Proc. Natl. Acad. Sci. 108, pp. 3047-3052.

65. Hennersdorf, P., Kleinertz, S., Theisen, S., Abdul-Aziz, M. A., Mrotzek, G., Palm, H. W., \& Saluz, H. P. (2016). Microbial diversity and parasitic load in tropical fish of different environmental conditions. PloS one, 11(3), e 0151594.

66. Hildebrandt, M. A., Hoffmann, C., Sherrill-Mix, S. A., Keilbaugh, S. A., Hamady, M., Chen, Y. Y., ... \& Wu, G. D. (2009). High-fat diet determines the composition of the murine gut microbiome independently of obesity. Gastroenterology, 137(5), pp. 17161724.

67. Hinestrosa, F., Madeira, R. G., \& Bourbeau, P. P. (2007). Severe gastroenteritis and hypovolemic shock caused by Grimontia (Vibrio) hollisae infection. Journal of clinical microbiology, 45(10), pp. 3462-3463.

68. Holben, W. E., P. Williams, M. Saarinen, L. K. Sarkilahti, \& J. H. A. Apajalahti. (2002). Phylogenetic analysis of intestinal microflora indicates a novel mycoplasma phylotype in farmed and wild salmon. Microb. Ecol. 44: pp. 175-185.

69. Huang, C. Y., Garcia, J. L., Patel, B. K., Cayol, J. L., Baresi, L., \& Mah, R. A. (2000). Salinivibrio costicola subsp. vallismortis subsp. nov., a halotolerant facultative anaerobe from Death Valley, and emended description of Salinivibrio costicola. International journal of systematic and evolutionary microbiology,50(2), pp. 615-622.

70. Hyun DW, Shin NR, Kim MS, Oh SJ, Kim PS, Whon TW, \& Bae JW. (2014). Endozoicomonas atrinae sp. nov., a bacterium isolated from the intestine of a comb pen shell Atrina pectinata. Int. J. Syst. Evol. Microbiol. 64, pp. 2312-2318.

71. Ingerslev, H. C., von Gersdorff Jørgensen, L., Strube, M. L., Larsen, N., Dalsgaard, I., Boye, M., \& Madsen, L. (2014). The development of the gut microbiota in rainbow trout (Oncorhynchus mykiss) is affected by first feeding and diet type. Aquaculture, 424, pp. 24-34.

72. Jiménez, E., Fernández, L., Marín, M. L., Martín, R., Odriozola, J. M., Nueno-Palop, C., ... \& Rodríguez, J. M. (2005). Isolation of commensal bacteria from umbilical cord blood of healthy neonates born by cesarean section. Current microbiology, 51(4), pp. 270-274.

73. Johnson, W. S., \& Ruben, P. (1988). Cleaning behavior of Bodianus rufus, Thalassoma bifasciatum, Gobiosoma evelynae, and Periclimenes pedersoni along a depth gradient at Salt River Submarine Canyon, St. Croix. Environmental Biology of Fishes, 23(3), pp. 225-232.

74. Kanther M. \& Rawls JF. (2010). Host-microbe interactions in the developing zebrafish. Curr Opin Immunol 22, pp. 10-19.

75. Karunasagar, I., Pai, R., Malathi, G. R., \& Karunasagar, I. (1994). Mass mortality of Penaeusmonodon larvae due to antibiotic-resistant Vibrio harveyi infection. Aquaculture, 128(3), pp. 203-209. 
76. Kavanagh, K. D. (2000). Larval brooding in the marine damselfish Acanthochromis polyacanthus (Pomacentridae) is correlated with highly divergent morphology, ontogeny and life-history traits. Bulletin of Marine Science, 66(2), pp. 321-337.

77. Kimes, N. E., Johnson, W. R., Torralba, M., Nelson, K. E., Weil, E., \& Morris, P. J. (2013). The Montastraea faveolata microbiome: ecological and temporal influences on a Caribbean reef-building coral in decline. Environmental microbiology, 15(7), pp. 20822094.

78. Klumpp, D. W., \& Polunin, N. V. C. (1989). Partitioning among grazers of food resources within damselfish territories on a coral reef. Journal of Experimental Marine Biology and Ecology, 125(2), pp. 145-169.

79. Kokita, T., \& Nakazono, A. (2001). Rapid response of an obligately corallivorous filefish Oxymonacanthus longirostris (Monacanthidae) to a mass coral bleaching event. Coral Reefs, 20(2), pp. 155-158.

80. Kozich, J.J., Westcott, S.L., Baxter, N.T., Highlander, S.K., \& Schloss, P.D. (2013). Development of a dual-index sequencing strategy and curation pipeline for analyzing amplicon sequence data on the MiSeq Illumina sequencing platform. Appl Environ Microbiol 79: pp. 5112- 5120.

81. Kubo, K., Lloyd, K. G., Biddle, J. F., Amann, R., Teske, A., \& Knittel, K. (2012). Archaea of the Miscellaneous Crenarchaeotal Group are abundant, diverse and widespread in marine sediments. The ISME journal, 6(10), pp. 1949-1965.

82. Lee WJ, \& Hase K. (2014). Gut microbiota-generated metabolites in animal health and disease. Nat Chem Biol., 10(6), pp. 416-24.

83. Leis JM (1991) The pelagic stage of reef fishes: the larval biology of coral reef fishes. In: Sale PF (ed) The ecology of fishes on coral reefs. Academic Press, San Diego, Calif. pp. $183-230$.

84. Leis, J. M., Sweatman, H. P., \& Reader, S. E. (1996). What the pelagic stages of coral reef fishes are doing out in blue water: daytime field observations of larval behavioural capabilities. Marine and Freshwater Research, 47(2), pp. 401-411.

85. Ley, R., Peterson, D., \& Gordon, J. (2006). Ecological and evolutionary forces shaping microbial diversity in the human intestine. Cell 124, pp. 837-848.

86. Llewellyn MS, Boutin S, Hoseinifar SH, \& Derome N. (2014). Teleost microbiomes: the state of the art in their characterization, manipulation and importance in aquaculture and fisheries. Front Microbiol. 5, p. 207.

87. Llewellyn, M. S., McGinnity, P., Dionne, M., Letourneau, J., Thonier, F., Carvalho, G. R., ... \& Derome, N. (2015). The biogeography of the atlantic salmon (Salmo salar) gut microbiome. The ISME journal.

88. Lobo, C., Moreno-Ventas, X., Tapia-Paniagua, S., Rodríguez, C., Moriñigo, M. A., \& de La Banda, I. G. (2014). Dietary probiotic supplementation (Shewanella putrefaciens Pdp11) modulates gut microbiota and promotes growth and condition in Senegalese sole larviculture. Fish physiology and biochemistry, 40(1), pp. 295-309.

89. Lozupone, C. A., Stombaugh, J. I., Gordon, J. I., Jansson, J. K., \& Knight, R. (2012). Diversity, stability and resilience of the human gut microbiota. Nature, 489(7415), pp. 220-230.

90. Luczkovich, J. J., \& Stellwag, E. J. (1993). Isolation of cellulolytic microbes from the intestinal tract of the pinfish, Lagodon rhomboides: size-related changes in diet and microbial abundance. Marine Biology, 116(3), pp. 381-388. 
91. Magarinos, B., Romalde, J.L., Noya, M., Barja, J.L., \& Toranzo, A.E., (1996). Adherence and invasive capacities of the fish pathogen Pasteurella piscicida. FEMS Microbiol. Lett. 138, pp. 29-34.

92. Magoč, T., \& Salzberg, S.L. (2011). FLASH: fast length adjustment of short reads to improve genome assemblies. Bioinformatics 27: pp. 2957-2963.

93. Macián, M. C., Garay, E., Grimont, P. A. D., \& Pujalte, M. J. (2004). Vibrio ponticus sp. nov., a neighbour of $V$. fluvialis- $V$. furnissii clade, isolated from gilthead sea bream, mussels and seawater. Systematic and applied microbiology, 27(5), pp. 535-540.

94. Marnane, M. J., \& Bellwood, D. R. (2002). Diet and nocturnal foraging in cardinalfishes (Apogonidae) at one tree reef, great barrier reef, Australia. Marine Ecology progress series, 231, pp. 261-268.

95. Martens, E. C., Kelly, A. G., Tauzin, A. S., \& Brumer, H. (2014). The devil lies in the details: how variations in polysaccharide fine-structure impact the physiology and evolution of gut microbes. Journal of molecular biology, 426(23), pp. 3851-3865.

96. Martin-Antonio, B., Manchado, M., Infante, C., Zerolo, R., Labella, A., Alonso, C., \& Borrego, J. J. (2007). Intestinal microbiota variation in Senegalese sole (Solea senegalensis) under different feeding regimes. Aquaculture research, 38: pp. 1213-1222.

97. McCauley, D. J., Micheli, F., Young, H. S., Tittensor, D. P., Brumbaugh, D. R., Madin, E. M., ... \& Worm, B. (2010). Acute effects of removing large fish from a near-pristine coral reef. Marine biology, 157, pp. 2739.

98. Miyake, S., Ngugi, D. K. \& Stingl, U. (2015), Diet strongly influences the gut microbiota of surgeonfishes. Molecular Ecology, 24, pp. 656-672.

99. Moeller AH, Li Y, Mpoudi Ngole E, Ahuka-Mundeke S, Lonsdorf EV, Pusey AE, Peeters M, Hahn BH, \& Ochman H. (2014). Rapid changes in the gut microbiome during human evolution. Proc Natl Acad Sci, 111(46), pp. 16431-5.

100.Mouchet, M. A., Bouvier, C., Bouvier, T., Troussellier, M., Escalas, A., \& Mouillot, D. (2012). Genetic difference but functional similarity among fish gut bacterial communities through molecular and biochemical fingerprints. FEMS microbiology ecology, 79(3), pp. 568-580.

101.Mumby P. J., Dahlgren, C. P., Harborne, A. R., Kappel, C. V., Micheli, F., Brumbaugh, D. R., ... \& Gill, A. B., (2006). Fishing, trophic cascades, and the process of grazing on coral reefs. Science 311, p. 98.

102.Nayak SK (2010). Role of gastrointestinal microbiota in fish. Aquaculture Research, 41, pp. 1553-1573.

103.Neave, M. J., Michell, C. T., Apprill, A., \& Voolstra, C. R. (2014). Whole-genome sequences of three symbiotic Endozoicomonas strains. Genome announcements, 2(4), e00802-14.

104.Nishijima M, Adachi K, Katsuta A, Shizuri Y, \& Yamasato K. (2013). Endozoicomonas numazuensis sp. nov., a gammaproteobacterium isolated from marine sponges, and emended description of the genus Endozoicomonas Kurahashi and Yokota 2007. Int. J. Syst. Evol. Microbiol. 63, pp. 709-714.

105.Onarheim, A. M., Wiik, R., Burghardt, J., \& Stackebrandt, E. (1994). Characterization and identification of two Vibrio species indigenous to the intestine of fish in cold sea water; description of Vibrio iliopiscarius sp. nov. Systematic and applied microbiology, 17(3), pp. 370-379. 
106.Papazisi, L., Gorton, T. S., Kutish, G., Markham, P. F., Browning, G. F., Swartzell, S., ... \& Geary, S. J. (2003). The complete genome sequence of the avian pathogen Mycoplasma gallisepticum strain Rlow. Microbiology, 149(9), pp. 2307-2316.

107.Pascual, J., Macián, M. C., Arahal, D. R., Garay, E., \& Pujalte, M. J. (2009). Description of Enterovibrio nigricans sp. nov., reclassification of Vibrio calviensis as Enterovibrio calviensis comb. nov. and emended description of the genus Enterovibrio Thompson et al. 2002. International journal of systematic and evolutionary microbiology, 59(4), pp. 698-704.

108.Patton, W.K. Community structure among the animals inhabiting the coral Pocillopora damicornis at Heron Island, Australia (1974). In Symbiosis in the Sea; Vernberg, W., Ed.; University of South Carolina Press: Columbia, SC, USA, pp. 219-243.

109.Pollak, P.E. \& W.L. Montgomery. (1994). Giant bacterium (Epulopiscium fishelsoni) influences digestive enzyme activity of an herbivorous surgeonfish (Acanthurus nigrofuscus). Comp. Biochem. Physiol, 108A. pp. 657-662.

110.Pratchett, M. S. (2007). Dietary selection by coral-feeding butterflyfishes (Chaetodontidae) on the Great Barrier Reef, Australia. Raffles Bull Zool, 14, pp. 171-176.

111.Pujalte Domarco, M. J., Sitjà Bobadilla, A., Álvarez Pellitero, P., \& Garay Auban, E. (2004). Carriage of potentially fish-pathogenic bacteria in Sparus aurata cultured in Mediterranean fish farms. Diseases of Aquatic Organisms, 54, pp. 119-126.

112.Randall, J. E. (1967). Food habits of reef fishes of the West Indies. Institute of Marine Sciences, University of Miami.

113.Rawls J., Samuel, B. S., \& Gordon, J. I., (2004). Gnotobiotic zebrafish reveal evolutionarily conserved responses to the gut microbiota. Proc Natl Acad Sci, 101, pp. 4596-4601.

114.Ray, A. K., Ghosh, K., \& Ringø, E. (2012). Enzyme-producing bacteria isolated from fish gut: a review. Aquaculture Nutrition, 18(5), pp. 465-492.

115.Reece, R. M., Cunha, C. B., \& Rich, J. D. (2014). Corynebacterium minutissimum vascular graft infection: Case report and review of 281 cases of prosthetic device-related Corynebacterium infection. Scandinavian journal of infectious diseases, 46(9), pp. 609616.

116.Roeselers, G., Mittge, E. K., Stephens, W. Z., Parichy, D. M., Cavanaugh, C. M., Guillemin, K., \& Rawls, J. F. (2011). Evidence for a core gut microbiota in the zebrafish. The ISME journal, 5(10), pp. 1595-1608.

117. Romalde, J. L. (2002). Photobacterium damselae subsp. piscicida: an integrated view of a bacterial fish pathogen. International Microbiology, 5(1), pp. 3-9.

118. Rotjan RD, and Lewis SM (2008). Impact of coral predators on tropical reefs. Mar Ecol Prog Ser 367, pp. 73-91.

119.Round, J. \& Mazmanian S. (2009). The gut microbiota shapes intestinal immune responses during health and disease. Nat Rev Immunol, 9, pp. 313-323.

120.Ruby, E. G., \& Nealson, K. H. (1976). Symbiotic association of Photobacterium fischeri with the marine luminous fish Monocentris japonica: a model of symbiosis based on bacterial studies. The Biological Bulletin, 151(3), pp. 574-586.

121.Sanchez, L. M., Wong, W. R., Riener, R. M., Schulze, C. J., \& Linington, R. G. (2012). Examining the fish microbiome: vertebrate-derived bacteria as an environmental niche for the discovery of unique marine natural products. PloS one, 7(5), e35398. 
122.Schmale, M. C., Hensley, G. T., \& Udey, L. R. (1986). Neurofibromatosis in the Bicolor Damselfish (Pomacentrus partitus) as a Model of von Recklinghausen Neurofibromatosisa. Annals of the New York Academy of Sciences, 486(1), pp. 386-402. 123.Schmidt, V.T., Smith, K.F., Melvin, D.W., \& Amaral-Zettler, L.A. (2015). Community assembly of a euryhaline fish microbiome during salinity acclimation. Molecular Ecology, 24, pp 2537-2550.

124. Shade A, \& Handelsman J. (2012). Beyond the Venn diagram: the hunt for a core microbiome. Environ Microbiol., 14(1), pp. 4-12.

125.Smriga, S., Sandin, S., \& Azam, F. (2010). Abundance, diversity, and activity of microbial assemblages associated with coral reef fish guts and feces. FEMS Microbiol Ecol, 73, pp. 31-42.

126.Spanggaard, B., I. Huber, J. Nielsen, T. Nielsen, K. F. Appel, \& L. Gram. (2000). The microflora of rainbow trout intestine: a comparison of traditional and molecular identification. Aquaculture, 182, pp. 1-15.

127.Sudakaran, S., Salem, H., Kost, C., \& Kaltenpoth, M. (2012). Geographical and ecological stability of the symbiotic mid-gut microbiota in European firebugs, Pyrrhocoris apterus (Hemiptera, Pyrrhocoridae). Molecular Ecology, 21(24), pp. 61346151.

128.Sullam, K.E., Essinger, S. D., Lozupone, C. A., O’CONNOR, M. P., Rosen, G. L., Knight, R. O. B., ... \& Russell, J. A. (2012). Environmental and ecological factors that shape the gut bacterial communities of fish: a meta-analysis. Molecular Ecology, 21, pp. 3363-3378.

129.Sullam, K. E., Rubin, B. E., Dalton, C. M., Kilham, S. S., Flecker, A. S., \& Russell, J. A. (2015). Divergence across diet, time and populations rules out parallel evolution in the gut microbiomes of Trinidadian guppies. The ISME journal, 9(7), pp. 1508-1522.

130.Theis KR, Venkataraman, A., Dycus, J. A., Koonter, K. D., Schmitt-Matzen, E. N., Wagner, A. P., ... \& Schmidt, T. M. (2013). Symbiotic bacteria appear to mediate hyena social odors. Proc Natl Acad Sci., 110, 49, pp. 19832-19837.

131.Thompson, F. L., Thompson, C. C., Naser, S., Hoste, B., Vandemeulebroecke, K., Munn, C., ... \& Swings, J. (2005). Photobacterium rosenbergii sp. nov. and Enterovibrio coralii sp. nov., vibrios associated with coral bleaching. International journal of systematic and evolutionary microbiology, 55(2), pp. 913-917.

132.Turnbaugh, P.J., Ley, R. E., Mahowald, M. A., Magrini, V., Mardis, E. R., \& Gordon, J. I. (2006). An obesity-associated gut microbiome with increased capacity for energy harvest, Nature, 444, pp. 1027-1031.

133.Turnbaugh PJ, Ridaura, V. K., Faith, J. J., Rey, F. E., Knight, R., \& Gordon, J. I. (2009a). The effect of diet on the human gut microbiome: A metagenomic analysis in humanized gnotobiotic mice. Sci Transl Med 1,6, 6ra14.

134. Turnbaugh, P. J., \& Gordon, J. I. (2009b). The core gut microbiome, energy balance and obesity. The Journal of physiology, 587(17), pp. 4153-4158.

135. Turnbaugh PJ, Hamady M, Yatsunenko T, Cantarel BL, Duncan A, Ley RE, Sogin ML, Jones WJ, Roe BA, Affourtit JP, Egholm M, Henrissat B, Heath AC, Knight R, \& Gordon JI. (2009c). A core gut microbiome in obese and lean twins. Nature, 457(7228), pp. 480-484. 
136. Van Der Maarel, M. J., Artz, R. R., Haanstra, R., \& Forney, L. J. (1998). Association of marine archaea with the digestive tracts of two marine fish species. Applied and environmental microbiology, 64(8), pp. 2894-2898.

137.Vasconcelos, A. T. R., Ferreira, H. B., Bizarro, C. V., Bonatto, S. L., Carvalho, M. O., Pinto, P. M., ... \& Martinkovics, C. T. (2005). Swine and poultry pathogens: the complete genome sequences of two strains of Mycoplasma hyopneumoniae and a strain of Mycoplasma synoviae. Journal of bacteriology, 187(16), pp. 5568-5577.

138. Vetriani C, Jannasch HW, MacGregor BJ, Stahl DA, \& Reysenbach AL. (1999). Population structure and phylogenetic characterization of marine benthic Archaea in deep-sea sediments. Appl Environ Microbiol., 10, pp. 4375-84.

139. Wada-Katsumata A, Zurek L, Nalyanya G, Roelofs WL, Zhang A, \& Schal C. (2015). Gut bacteria mediate aggregation in the German cockroach. Proceedings of the National Academy of Sciences of the United States of America, 112(51), pp. 15678-15683.

140.Wakabayashi H., Sawada K., Ninomiya K., \& Nishimori E. (1996). Bacterial hemorrhagic ascites of ayu caused by Pseudomonas sp. Fish Pathol. 31, pp. 239-240.

141.Ward, N. L., B. Steven, K. Penn, B. A. Methé, \& W. H. Detrich. (2009). Characterization of the intestinal microbiota of two Antarctic notothenioid fish species. Extremophiles, 13, pp. 679-685.

142.Wellington, G. M., \& Victor, B. C. (1989). Planktonic larval duration of one hundred species of Pacific and Atlantic damselfishes (Pomacentridae). Marine Biology, 101(4), pp. 557-567.

143. Whitman WB, Coleman DC, \& Wiebe WJ (1998). Prokaryotes: the unseen majority. Proc Natl Acad Sci 95, pp. 6578-6583.

144.Wilson S., \& Bellwood D. 1997. Cryptic dietary components of territorial damselfishes (Pomacentridae, Labroidei). Mar. Ecol. Prog. Ser. 153, pp. 299-310.

145.Wilson, S. K., Burgess, S. C., Cheal, A. J., Emslie, M., Fisher, R., Miller, I., ... \& Sweatman, H. (2008). Habitat utilization by coral reef fish: implications for specialists vs. generalists in a changing environment. Journal of Animal Ecology, 77(2), pp. 220-228.

146.Wong, S., \& Rawls, J. F. (2012). Intestinal microbiota composition in fishes is influenced by host ecology and environment. Molecular ecology, 21(13), pp. 3100-3102.

147.Xing, M., Hou, Z., Yuan, J., Liu, Y., Qu, Y., \& Liu, B. (2013). Taxonomic and functional metagenomic profiling of gastrointestinal tract microbiome of the farmed adult turbot (Scophthalmus maximus). FEMS Microbiology Ecology, 86(3), pp. 432-443.

148. Ye L, Amberg J, Chapman D, Gaikowski M, \& Liu WT. (2014). Fish gut microbiota analysis differentiates physiology and behavior of invasive Asian carp and indigenous American fish. ISME J., 8, pp. 541-551.

149.Yoshitomo, K., Xian-Ying, M., \& Takema, F. (2005). Gut symbiotic bacteria of the genus Burkholderia in the broad-headed bugs Riptortus clavatus and Leptocorisa chinensis (Heteroptera: Alydidae). Applied and Environmental Microbiology, 71, pp. 4035-4043.

150.Zheng X, Zhao, A., Xie, G., Chi, Y., Zhao, L., Li, H., ... \& Jia, W. (2013). Melamineinduced renal toxicity is mediated by the gut microbiota. Sci Transl Med., 5, 172, $172 \mathrm{ra} 22$. 
$889 \quad$ Table and Figures

890 Table 1. Median \% abundance of bacterial Families* in pre- versus post-settlement

891 damselfish and cardinalfish (pooled).

\begin{tabular}{lccccc}
\multicolumn{1}{c}{ Family } & \multicolumn{2}{c}{ Pre } & \multicolumn{2}{c}{ Post } \\
\cline { 5 - 6 } & med & MAD & med & MAD & Fold \\
\hline Vibrionaceae & 18.12 & 14.20 & 41.91 & 28.69 & 2.31 \\
Endozoicimonaceae** & 11.02 & 9.50 & 0.14 & 0.14 & $\underline{76.40}$ \\
Pseudoalteromonadaceae & 1.28 & 1.15 & 0.45 & 0.42 & $\underline{2.83}$ \\
Rhodobacteraceae & 1.24 & 1.01 & 1.35 & 1.22 & 1.09 \\
Flavobacteriaceae & 1.07 & 0.89 & 0.61 & 0.60 & $\underline{1.75}$ \\
Alteromonadaceae & 0.71 & 0.63 & 0.85 & 0.75 & 1.20 \\
Shewanellaceae & 0.68 & 0.65 & 0.11 & 0.11 & $\underline{5.99}$ \\
Oceanospirillaceae & 0.56 & 0.51 & 0.15 & 0.15 & $\underline{3.74}$ \\
Pseudomonadaceae & 0.29 & 0.24 & 0.49 & 0.45 & 1.70 \\
Moraxellaceae & 0.26 & 0.23 & 0.02 & 0.02 & $\underline{10.31}$ \\
Pirellulaceae** & 0.01 & 0.01 & 0.83 & 0.81 & 81.97 \\
Chromatiales, Unknown & 0.10 & 0.08 & 0.21 & 0.20 & 2.03 \\
\hline
\end{tabular}

*only includes Families with median abundance $>0.2 \%$ in either pre or post datasets

$* *$ significant change pre vs. post ( $P<0.05$, ANOVA, Bonferroni corrected)

MAD, median absolute deviation

Fold, fold increase in median (pre to post); underlined indicates post to pre 
894 Table 2. Indicator genera associated with pre- and post-settlement damselfish and

895 cardinalfish (pooled).

\begin{tabular}{|c|c|c|c|}
\hline Indicator genera & Indicator for pre or post settlement fish & Indicator value & p-value \\
\hline Kordia & Pre & 0.943 & 0.001 \\
\hline Halomonas & Pre & 0.896 & 0.001 \\
\hline Arcobacter & Pre & 0.869 & 0.001 \\
\hline Oceanospirillum & Pre & 0.823 & 0.001 \\
\hline Idiomarina & Pre & 0.751 & 0.002 \\
\hline unclassified Vibrionaceae & Post & 0.997 & 0.01 \\
\hline unclassified Pirellulaceae & Post & 0.922 & 0.001 \\
\hline unclassified Kiloniellales & Post & 0.904 & 0.001 \\
\hline unclassified Gammaproteobacteria & Post & 0.9 & 0.001 \\
\hline Coraliomargarita & Post & 0.863 & 0.001 \\
\hline Portiera & Post & 0.857 & 0.001 \\
\hline Epulopiscium & Post & 0.857 & 0.001 \\
\hline unclassified Hyphomicrobiaceae & Post & 0.851 & 0.001 \\
\hline Verrucomicrobium & Post & 0.816 & 0.001 \\
\hline unclassified Rhizobiales & Post & 0.786 & 0.001 \\
\hline Rhodospirillaceae & Post & 0.779 & 0.001 \\
\hline unclassified Acidimicrobiales OCS155 & Post & 0.778 & 0.001 \\
\hline unclassified Oceanospirillales & Post & 0.771 & 0.001 \\
\hline unclassified Peptostreptococcaceae & Post & 0.771 & 0.001 \\
\hline unclassified Myxococcales & Post & 0.768 & 0.001 \\
\hline unclassified Altermonadales OM60 & Post & 0.763 & 0.013 \\
\hline unclassified Phyllobacteriaceae & Post & 0.761 & 0.001 \\
\hline Ferrimonas & Post & 0.75 & 0.001 \\
\hline unclassified Thiohalorhabdales & Post & 0.746 & 0.001 \\
\hline unclassified Flavobacteriales & Post & 0.743 & 0.001 \\
\hline unclassified Cryomorphaceae & Post & 0.733 & 0.038 \\
\hline unclassified Altermonadales & Post & 0.733 & 0.038 \\
\hline unclassified Myxococcales OM27 & Post & 0.728 & 0.001 \\
\hline Balneola & Post & 0.724 & 0.001 \\
\hline Crocinitomix & Post & 0.723 & 0.001 \\
\hline unclassified Flammeovirgaceae & Post & 0.722 & 0.002 \\
\hline unclassified Altermonadaceae & Post & 0.722 & 0.035 \\
\hline unclassified Francisellaceae & Post & 0.712 & 0.001 \\
\hline Saprospria & Post & 0.692 & 0.003 \\
\hline Clostridium & Post & 0.692 & 0.016 \\
\hline unclassified Rickettsiales & Post & 0.688 & 0.001 \\
\hline Turicibacter & Post & 0.682 & 0.001 \\
\hline unclassified Deltaproteobacteria GMD14H09 & Post & 0.678 & 0.006 \\
\hline unclassified Pasteurellaceae & Post & 0.676 & 0.002 \\
\hline unclassified Actinomycetales & Post & 0.675 & 0.001 \\
\hline Altermonadaceae HTCC2207 & Post & 0.67 & 0.001 \\
\hline unclassified Comamonadaceae & Post & 0.664 & 0.004 \\
\hline Flavobacterium & Post & 0.656 & 0.003 \\
\hline
\end{tabular}




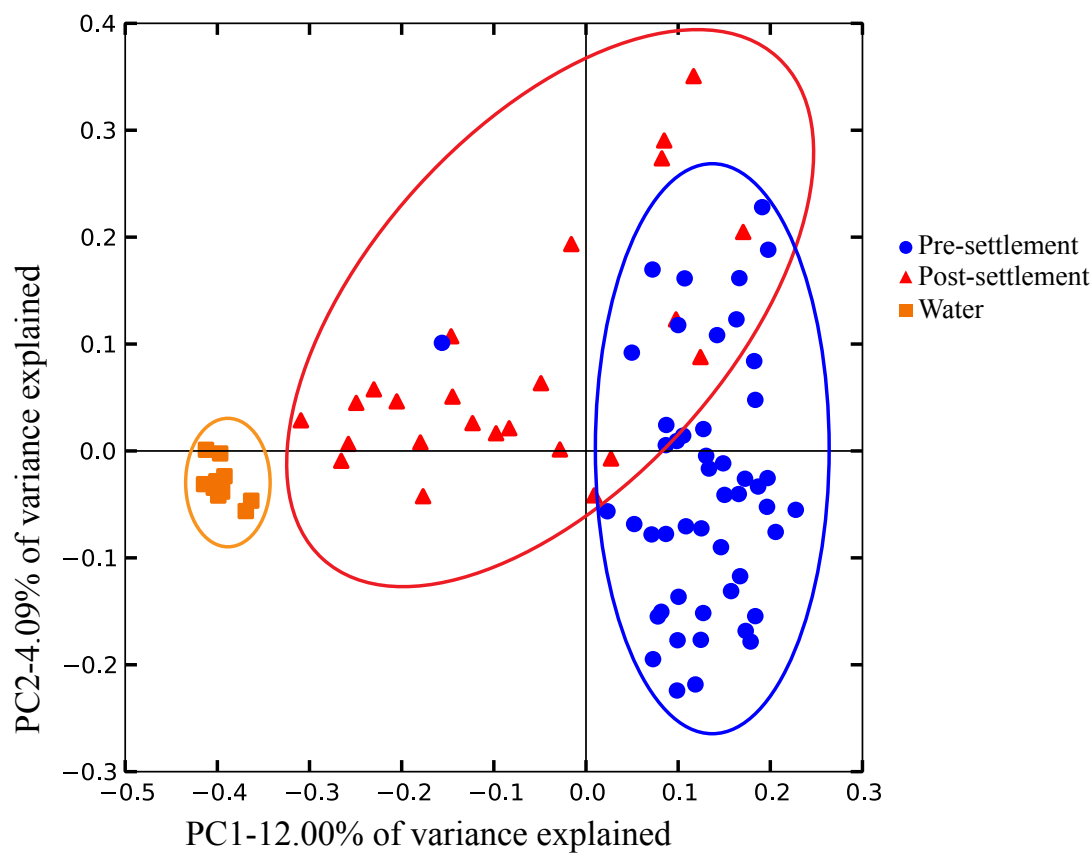

898 Figure 1. Compositional relatedness of microbiome samples. Principal coordinate analysis 899 based on unweighted Unifrac distance with sequence data rarified to 4262 sequences per 900 sample (49 pre-settlement, 24 post-settlement, 11 seawater samples). According to a two901 sided t-test (Bonferroni-corrected), pre-settlement and post-settlement individuals are 902 significantly different from one another $(\mathrm{p}<0.05)$ and both are significantly different from 903 the water column $(\mathrm{p}<0.05)$ based on unweighted Unifrac distance. 


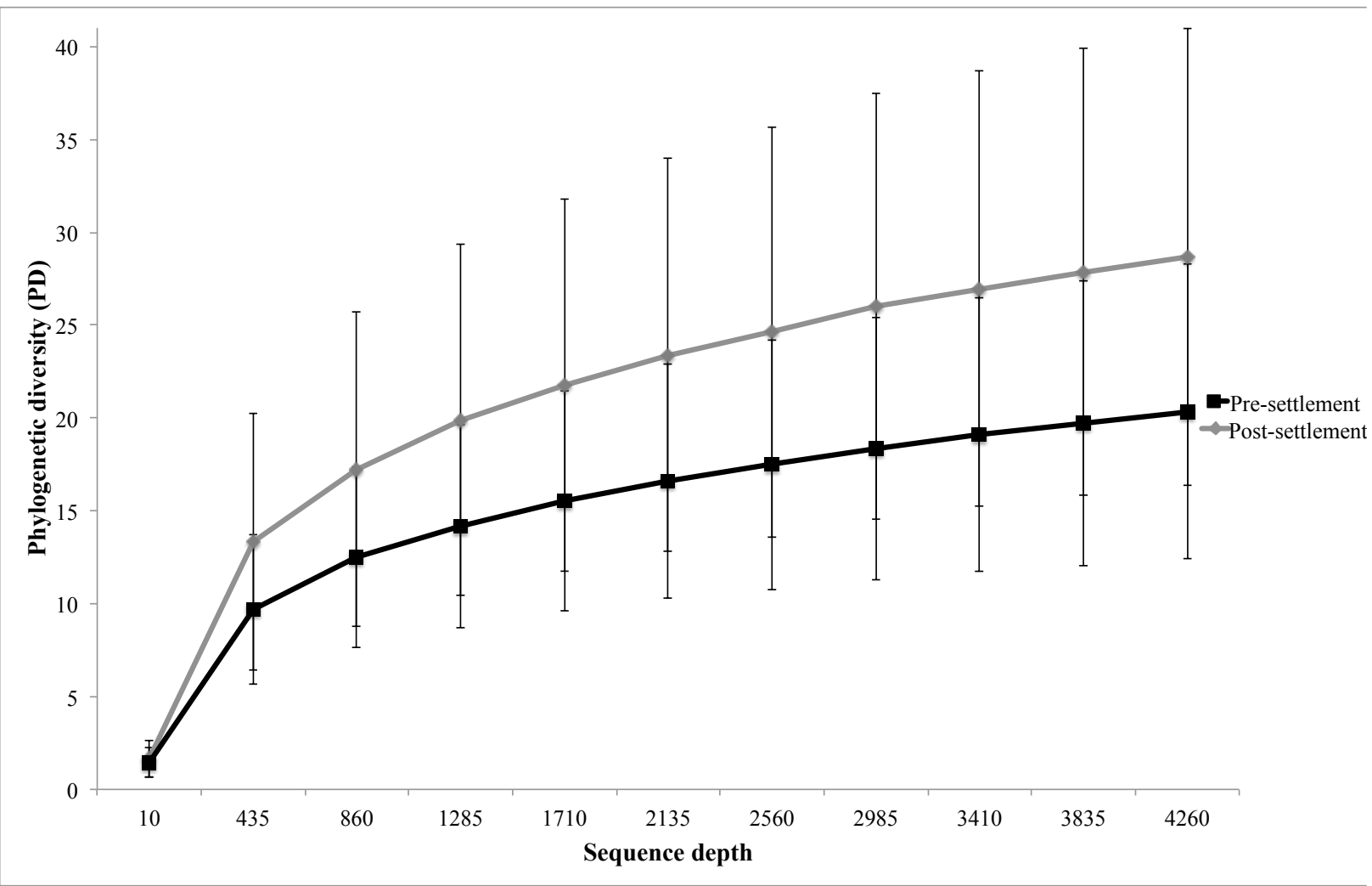

906

Figure 2. Microbiome phylogenetic diversity (PD) as a function of sequence depth in pre-

907 and post-settlement fish (all species combined, based on data rarified to 4262 sequences

908 per sample). Error bars are \pm 1 standard error.

909 


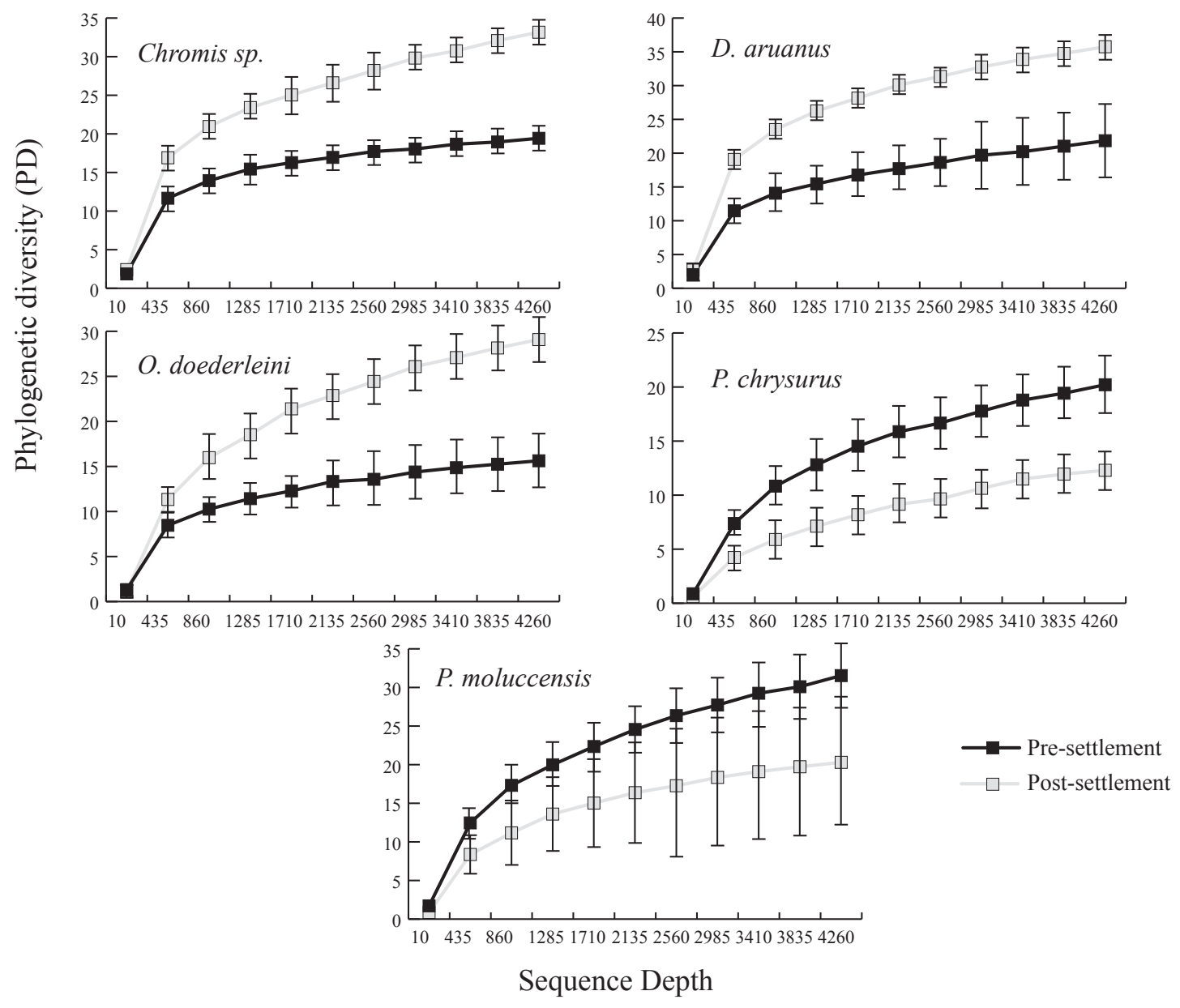

911 Figure 3. Microbiome phylogenetic diversity (PD) as a function of sequence depth in five

912 species represented in both pre- and post-settlement datasets. Error bars are \pm 1 standard 913 error. 


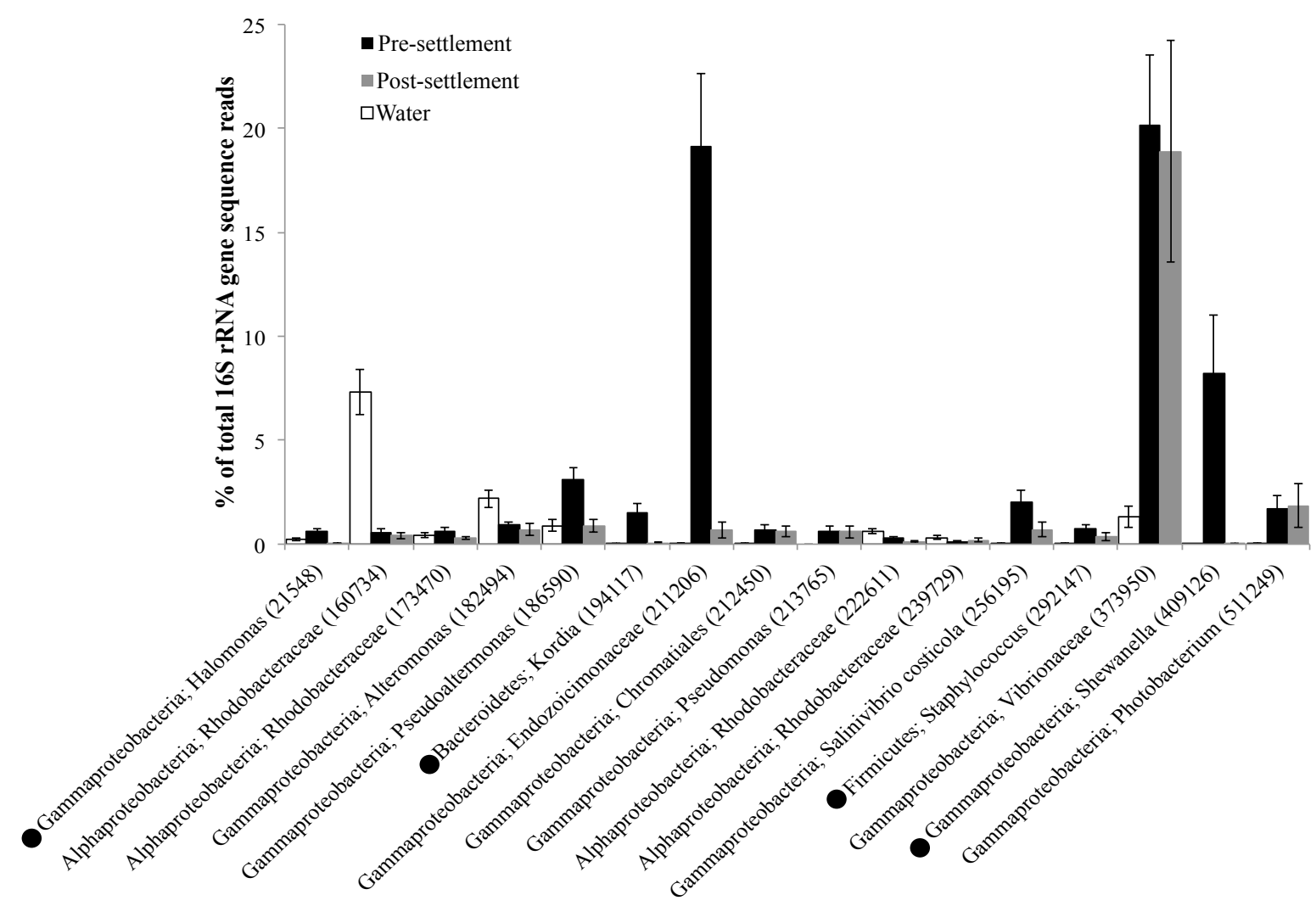

916 Figure 4. Taxonomic identity and relative abundance of OTUs detected in greater than 70\%

917 of all fish microbiome samples (pre-settlement $(n=49)$ and post-settlement $(n=24)$ samples) combined for analysis. $\bullet$ indicates that an OTU was shared among $70 \%$ of the pre-settlement samples when this sample set was evaluated independently, but was not detected in $>70 \%$ of samples in the post-settlement set when evaluated independently.

921 The relative abundances of these OTUs in the water column samples $(n=11)$ are included

922 for comparison. Taxonomic classifications are at the level of genus whenever possible.

923 Error bars are \pm 1 standard error. 